\title{
Potentially Synbiotic Grape Juice: What is the Impact of The Addition of Lacticaseibacillus casei and Prebiotic Components?
}

\author{
José Victor de Carvalho Silva ${ }^{1}$, Ariane Dantas da Silva ${ }^{1}$, Suellen Jensen Klososki ${ }^{1}$ (D), Carlos Eduardo \\ Barão ${ }^{1(i)}$, Tatiana Colombo Pimentel 1,* (D) \\ 1 Federal Institute of Paraná, Paranavaí, Paraná, 87703-536, Brazil; carvalho-vitor@hotmail.com (J.V.C.S.); \\ ariane_dantas1@hotmail.com (A.D.S.); suellen.jensen@ifpr.edu.br (S.J.K.); carlos.barao@ifpr.edu.br (C.E.B.); \\ tatiana.pimentel@ifpr.edu.br (T.C.P.); \\ * Correspondence: tatiana.pimentel@ifpr.edu.br;
}

Scopus Author ID 53878430400

Received: 16.10.2020; Revised: 10.11.2020; Accepted: 12.11.2020; Published: 14.11.2020

\begin{abstract}
The objective of this study was to evaluate the impact of the addition of oligofructose or polydextrose $(2 \mathrm{~g} / 100 \mathrm{~g})$ and Lacticaseibacillus casei $(2 \mathrm{~g} / \mathrm{L})$ on the quality parameters of grape juices during storage $\left(7{ }^{\circ} \mathrm{C} / 28\right.$ days in polyethylene terephthalate flasks). The addition of probiotics or prebiotics did not alter the physicochemical characteristics, texture properties, and storage stability of the grape juices; however, they changed the color and/or turbidity. Oligofructose and polydextrose did not show a protective effect on the probiotic, but the products showed probiotic viability higher than $10^{6} \mathrm{CFU} / \mathrm{mL}$. The grape juice with oligofructose had similar acceptance to the control juice. The addition of polydextrose or reduced probiotic acceptance in most of the evaluated attributes. All grape juices presented scores higher than 6 on a 9-point hedonic scale and an acceptability index higher than $70 \%$. It is possible to produce potentially synbiotic grape juices with suitable quality parameters, probiotic survival, and sensory acceptance.
\end{abstract}

Keywords: oligofructose; package; polydextrose; probiotic; Vitis vinifera.

(C) 2020 by the authors. This article is an open-access article distributed under the terms and conditions of the Creative Commons Attribution (CC BY) license (https://creativecommons.org/licenses/by/4.0/).

\section{Introduction}

Probiotics are living microorganisms that confer beneficial effects to the host when administered in adequate amounts [1,2]. The consumption of Lacticaseibacillus casei as a probiotic culture has been associated with several health benefits, such as improvement in the blood pressure and lipid indexes [3], reduction in the oxidative stress in the lungs, gut, and liver [4], protection against Salmonella enterica ssp. enterica serovar Typhimurium infection [5], anti-hyperglycemic properties [6], anticarcinogenic properties [7], among others.

Dairy products, such as fermented milk, ice creams, and cheeses, are the main products added with probiotic cultures [8-10]. Recently, there was a demand for non-dairy probiotic products, mainly because of the increase in the number of individuals with lactose intolerance, milk allergy, and vegans [11,12]. Fruit juices can be suitable carriers for probiotic cultures because of the rich nutritional composition, consumption by all age groups on a regular basis, and no allergenic compounds [13]. Grape juice presents a high concentration of polyphenolic compounds, which are related to anti-inflammatory properties, antioxidant activities, and protection against cardiovascular diseases [14,15]. 
The traditional methodology to incorporate a probiotic culture in fruit juices is to activate it in Man Rogosa and Sharp (MRS) broth, separate in a centrifuge, dissolve the biomass in a saline solution and incorporate into the juices [16]. The addition of probiotic cultures in the freeze-dried form is a time-consuming technique; however, it can negatively impact the sensory characteristics and on the probiotic survival, as the microorganism is not in its active form [8]. Studies involving the addition of freeze-dried probiotic cultures to fruit juices are still scarce [8,17], and presented conflicting results, as no impact [17] or high decrease [8] in the sensory acceptance of the products by consumers were observed.

The type of food packaging has an important role in probiotic viability, as the probiotic cultures are generally microaerophilic or anaerobic, and, thus, the exposure to oxygen can be lethal. Glass packages favor probiotic survival due to the low oxygen permeability, but they have a high cost. Therefore, plastic packages are preferred by the industries [16]. Most of the studies involving probiotic fruit juices used glass flasks to store the products $[8,13,17-20]$. Only one study used PET bottles [16], but the juice was pasteurized inside the bottles. Therefore, plastic compounds could have migrated to the juice and decreased the probiotic viability.

Prebiotics are non-viable food components that confer health benefits to the host associated with the modulation of the microbiota [21]. Inulin-type fructans (inulin and oligofructose), galactooligosaccharides, polydextrose, and fructooligosaccharides are the most used prebiotic components [22,23]. The addition of prebiotic components to fruit juices can increase probiotic survival [13] and result in improvements in the sensory and physicochemical characteristics of the products [11]. However, the positive influence of the prebiotic components on probiotic survival is not a consensus, as previous studies observed an increase in the probiotic counts [16], while others reported no impact $[8,13,24]$.

As far as the authors know, there are no reports on grape juices added with probiotic and prebiotic components. Furthermore, the utilization of PET packages and the addition of the probiotic culture in the freeze-dried form are factors that need further studies. Therefore, the objective of this study was to evaluate the impact of the addition of probiotic cultures (L. casei) and prebiotic components (oligofructose or polydextrose) on the physicochemical characteristics, color parameters, texture properties, probiotic survival, and sensory acceptance of grape juices during refrigerated storage $\left(7^{\circ} \mathrm{C} / 28\right.$ days in PET flasks).

\section{Materials and Methods}

\subsection{Materials.}

Oligofructose (Orafti® P95, DP=4-5, Mannheim, Germany), polydextrose (STA-III, Tate \& Lyle ${ }^{\circledR}$, DP $=9-10$, London, United Kingdom), L. casei (L. casei-01, Christian Hansen $\left.{ }^{\circledR}\right)$, and plastic (PET) flasks (Farma $\left.{ }^{\circledR}, 50 \mathrm{~mL}\right)$ were used in the experiment.

\subsection{Grape juice processing.}

The grape juice was processed in an industry in the city of Paranavaí, Paraná, Brazil. Grapes (Vitis vinifera) were selected and submitted to the juice extraction. The juice was heattreated in a plate exchanger, clarified, packed in PET bottles $(900 \mathrm{~mL})$, and refrigerated $\left(7^{\circ} \mathrm{C}\right)$.

Six formulations were prepared: CONT (control, without probiotic or prebiotic), PRO (with $2 \mathrm{~g} / \mathrm{L}$ of L. casei), OLIG (with $20 \mathrm{~g} / \mathrm{L}$ of oligofructose), POLY (with $20 \mathrm{~g} / \mathrm{L}$ of polydextrose), SYN-O (with $2 \mathrm{~g} / \mathrm{L}$ of L. casei and $20 \mathrm{~g} / \mathrm{L}$ of oligofructose), and SYN-P (with 
$2 \mathrm{~g} / \mathrm{L}$ of $L$. casei and $20 \mathrm{~g} / \mathrm{L}$ of polydextrose). The pasteurized juices were added with the probiotic culture or prebiotic components in an aseptic environment and stored in PET flasks for 28 days at $7{ }^{\circ} \mathrm{C}$. The concentration of the prebiotic components was based on previous studies that suggested a minimum daily consumption of 2-4 $\mathrm{g}$ of oligofructose or polydextrose $[25,26]$.

2.3 Physicochemical characteristics, color parameters, texture properties, and probiotic survival.

The $\mathrm{pH}$ of the juices was determined using a potentiometer (MS Tecnopon Instrumentation, mPA210, Piracicaba, Brazil). The titratable acidity was determined according to the methodology of AOAC [27] and expressed as \% tartaric acid. The total soluble solids (TSS) content was determined in a digital refractometer (Instruterm, São Paulo, Brazil) and expressed as ${ }^{\circ}$ Brix. The color parameters $\left(\mathrm{L}^{*}, \mathrm{a}^{*}\right.$, and $\left.\mathrm{b}^{*}\right)$ were determined in a colorimeter (Konica Minolta, CR-400, Osaka, Japan). The turbidity was determined in a spectrophotometer (T80, UV/VIS Spectrometer, PG Instruments Ltd., United Kingdom) at $600 \mathrm{~nm}$ wavelength [28].

The total phenolic compounds (TPC) were determined by spectrophotometric analysis according to the methodology described by Slinkard and Singleton [29]. The calibration curve was obtained using eleven dilutions of gallic acid (0-100 mg/L) and had $\mathrm{R}^{2}=0.9981$. Measurements of absorbances as a function of concentration were made on a UV/VIS spectrophotometer (Spectrometer PG Instruments Ltd.®) at $760 \mathrm{~nm}$. The results were expressed as milligram equivalent of gallic acid per liter (mg EAG/L).

The texture parameters (firmness, cohesiveness, consistency, and viscosity index) were determined using a TATX Express Texturometer (Stable Micro Systems, London, England). The formulations $(40 \mathrm{~mL})$, in plastic containers of $55 \mathrm{~mm}$ diameter and $60 \mathrm{~mm}$ height, were compressed by a cylindrical probe of $36 \mathrm{~mm}$ diameter (P36 R), $10 \mathrm{~mm}$ depth, pretest and test speeds of $1 \mathrm{~mm} / \mathrm{s}$, posttest speed of $10 \mathrm{~mm} / \mathrm{s}$, and trigger of $1 \mathrm{~g}$ [13].

L. casei counts were determined in MRS agar (Himedia ${ }^{\circledR}$, Mumbai, India) and anaerobic incubation (Anaerobac, Probac $®$ ) at $37{ }^{\circ} \mathrm{C}$ for $72 \mathrm{~h}[30]$.

\subsection{Sensory evaluation.}

The grape juice formulations were evaluated by 87 consumers ( 47 women and 40 men), ranging from 15 to over 50 years old, with the majority ( 75 individuals) being 15-25 years old. The acceptance test (appearance, aroma, flavor, texture, and overall impression) was carried out using a 9-point hedonic scale $(1=$ disliked very much and $9=$ liked very much); and the purchase intention test was done using a 5-point scale $(1=$ certainly would not buy, $5=$ certainly would buy) (Batista et al. 2017). The consumers were asked to describe which attributes they disliked in the products. The formulations were evaluated in a monadic form and in random order. The formulations $(25 \mathrm{~mL})$ were served in plastic cups $(50 \mathrm{~mL})$, coded with random three-digit numbers, and at $7{ }^{\circ} \mathrm{C}$. Potable water $\left(25^{\circ} \mathrm{C}\right)$ was available for palate cleansing. The acceptability index was calculated according to Dutcocky [31].

\subsection{Statistical analysis.}

The experiment followed a completed randomized design and was repeated twice. All analyses were done in triplicates. The physicochemical characteristics, color parameters, 
texture properties, and probiotic survival were evaluated on 1, 7, 14, 21, and 28 days of storage. Acceptance and purchase intention was performed on the $1^{\text {st }}$ day of storage. A split-plot design was used to analyze the data, being the formulations of the main treatment and the storage time of the secondary treatment. The results were submitted to Analysis of Variance (ANOVA) and Tukey test $(\mathrm{p}=0.05)$ using XLSTAT 2019.2 and SISVAR software.

\section{Results and Discussion}

\subsection{Physicochemical characteristics and color parameters.}

The physicochemical characteristics of the grape juices are shown in Table 1. The juices presented a $\mathrm{pH}$ of 2.88-3.18, titratable acidity of $0.43-0.58 \%$ tartaric acid, TSS of 12.82-15.58 ${ }^{\circ}$ Brix, and TPC of 1,437.46-2,006.52 mg EAG/L, previous corroborating studies with grape juices $[32,33]$. All formulations showed similar values of $\mathrm{pH}$ and titratable acidity $(\mathrm{p}>0.05)$, suggesting that the addition of probiotic culture, oligofructose, and polydextrose had no influence on these parameters. The maintenance of the acidity of the juices after probiotic addition indicates that there was no fermentative process, an important character from the sensory point of view, as too high acidity could cause decreases in the acceptance of the product by consumers. Furthermore, it can compromise the viability of the probiotic cultures [16].

During storage, the $\mathrm{pH}$ values were maintained similar on days 1 and 28 of storage (p $>0.05$ ), and the addition of the probiotic culture (PRO, SYN-O, and SYN-P) resulted in higher $\mathrm{pH}$ stability. Furthermore, the titratable acidity was maintained or slightly increased during storage, with no differences $(\mathrm{p}>0.05)$ between the formulations added with probiotic culture or prebiotic components and the control juice. Slightly increases in the acidity are related to the degradation of sugars in acids or dissociation of weakly acids [20].

The addition of the probiotic culture did not impact the TSS values $(\mathrm{p}>0.05)$, whereas the addition of the prebiotic components increased them $(\mathrm{p}<0.05)$. Oligofructose and polydextrose are soluble oligosaccharides, and their addition to foods can cause an increase in the TSS content $[8,13]$. During storage, there was a decrease in the TSS values of the control and prebiotic formulations ( $\mathrm{p}<0.05$ ), which could be associated with the decomposition of sugars $[8,20]$. For the formulations added with probiotic cultures, the TSS values were similar on the $1^{\text {st }}$ and $28^{\text {th }}$ of storage ( $\mathrm{p}>0.05$ ), suggesting that the probiotic culture increased the stability during storage.

The addition of the probiotic culture and prebiotic components did not influence the TPC content of the products $(\mathrm{p}>0.05)$. During storage, there was a maintenance in the TPC content of the formulations ( $p>0.05$, except SYN-O). Phenolic compounds can suffer from chemical and/or enzymatic oxidation if exposed to improper conditions of processing or prolonged storage time [8]. Therefore, the results suggest good conditions for processing and storage. It is suggested the consumption of $1 \mathrm{~g} /$ day of phenolic compounds. Thus, it would be necessary to consume two cups $(550-700 \mathrm{~mL}$ ) of the grape juices to achieve the recommended dosage. It is important to mention that there are other foods and fruits that have these compounds in their composition, and grape juices could be one of the options to acquire the necessary amount that is recommended. Phenolic compounds are also responsible for astringency, color, aroma, and oxidative stability of fruit juices [8], suggesting that these properties were maintained in the products. 
Table 1. Physicochemical characteristics of the grape juice formulations.

\begin{tabular}{|c|c|c|c|c|c|c|c|}
\hline Parameter & $\begin{array}{l}\text { Storage time } \\
\text { (Days) }\end{array}$ & CONT & OLIG & POLY & PRO & SYN-O & SYN-P \\
\hline \multirow[t]{5}{*}{$\mathrm{pH}$} & 1 & $2.92 \pm 0.11^{\mathrm{aAB}}$ & $2.92 \pm 0.11^{\mathrm{aAB}}$ & $2.92 \pm 0.10^{\mathrm{aAB}}$ & $3.04 \pm 0.10^{\mathrm{aA}}$ & $3.03 \pm 0.10^{\mathrm{aA}}$ & $3.03 \pm 0.10^{\mathrm{aA}}$ \\
\hline & 7 & $2.91 \pm 0.13^{\mathrm{aB}}$ & $2.90 \pm 0.15^{\mathrm{aB}}$ & $2.88 \pm 0.15^{\mathrm{aB}}$ & $3.02 \pm 0.13^{\mathrm{aA}}$ & $3.00 \pm 0.13^{\mathrm{aA}}$ & $3.00 \pm 0.14^{\mathrm{aA}}$ \\
\hline & 14 & $3.04 \pm 0.15^{\mathrm{aAB}}$ & $3.06 \pm 0.13^{\mathrm{aAB}}$ & $3.03 \pm 0.15^{\mathrm{aAB}}$ & $3.14 \pm 0.14^{\mathrm{aA}}$ & $3.13 \pm 0.13^{\mathrm{aA}}$ & $3.14 \pm 0.14^{\mathrm{aA}}$ \\
\hline & 21 & $2.98 \pm 0.23^{\mathrm{aAB}}$ & $2.97 \pm 0.24^{\mathrm{aAB}}$ & $2.94 \pm 0.22^{\mathrm{aAB}}$ & $3.02 \pm 0.17^{\mathrm{aA}}$ & $3.02 \pm 0.17^{\mathrm{aA}}$ & $3.05 \pm 0.21^{\mathrm{aA}}$ \\
\hline & 28 & $3.10 \pm 0.18^{\mathrm{aA}}$ & $3.09 \pm 0.18^{\mathrm{aA}}$ & $3.07 \pm 0.18^{\mathrm{aA}}$ & $3.18 \pm 0.16^{\mathrm{aA}}$ & $3.18 \pm 0.15^{\mathrm{aA}}$ & $3.17 \pm 0.14^{\mathrm{aA}}$ \\
\hline \multirow[t]{5}{*}{$\begin{array}{l}\text { Titratable } \\
\text { acidity }\end{array}$} & 1 & $0.45 \pm 0.03^{\mathrm{aA}}$ & $0.45 \pm 0.05^{\mathrm{aB}}$ & $0.44 \pm 0.04^{\mathrm{aB}}$ & $0.44 \pm 0.05^{\mathrm{aB}}$ & $\begin{array}{ll}0.48 & \pm \\
0.01^{\mathrm{aAB}} & \\
\end{array}$ & $0.47 \pm 0.02^{\mathrm{aB}}$ \\
\hline & 7 & $0.46 \pm 0.02^{\mathrm{aA}}$ & $0.44 \pm 0.04^{\mathrm{aB}}$ & $0.47 \pm 0.04^{\mathrm{aAB}}$ & $0.44 \pm 0.03^{\mathrm{aB}}$ & $0.44 \pm 0.05^{\mathrm{aB}}$ & $0.43 \pm 0.06^{\mathrm{aB}}$ \\
\hline & 14 & $0.48 \pm 0.06^{\mathrm{aA}}$ & $0.45 \pm 0.02^{\mathrm{aAB}}$ & $0.46 \pm 0.02^{\mathrm{aAB}}$ & $\begin{array}{ll}0.47 & \pm \\
0.01^{\mathrm{aAB}} & \\
\end{array}$ & $0.45 \pm 0.02^{\mathrm{aB}}$ & $0.46 \pm 0.04^{\mathrm{aB}}$ \\
\hline & 21 & $0.48 \pm 0.03^{\mathrm{aA}}$ & $0.48 \pm 0.03^{\mathrm{aAB}}$ & $0.49 \pm 0.01^{\mathrm{aAB}}$ & $\begin{array}{ll}0.51 & \pm \\
0.01^{\mathrm{aAB}} & \end{array}$ & $\begin{array}{l}0.50 \\
0.03^{\mathrm{aAB}}\end{array}$ & $0.50 \pm 0.03^{\mathrm{aAB}}$ \\
\hline & 28 & $0.53 \pm 0.15^{\mathrm{aA}}$ & $0.55 \pm 0.14^{\mathrm{aA}}$ & $0.56 \pm 0.13^{\mathrm{aA}}$ & $0.57 \pm 0.13^{\mathrm{aA}}$ & $0.57 \pm 0.13^{\mathrm{aA}}$ & $0.58 \pm 0.13^{\mathrm{aA}}$ \\
\hline $\begin{array}{l}\text { Total } \\
\text { soluble } \\
\text { solids }\end{array}$ & 1 & $14.53 \pm 1.49^{\mathrm{cA}}$ & $15.58 \pm 1.02^{\mathrm{aA}}$ & $15.47 \pm 0.61^{\mathrm{abA}}$ & $\begin{array}{l}13.70 \\
0.54^{\mathrm{CAB}}\end{array}$ & $\begin{array}{l}15.18 \\
0.56^{\mathrm{abA}}\end{array}$ & $\begin{array}{l}14.95 \\
0.73^{\mathrm{aAB}}\end{array}$ \\
\hline & 7 & $\begin{array}{l}13.52 \\
0.10^{\mathrm{bBC}} \\
\end{array}$ & $\begin{array}{l}15.10 \\
0.23^{\mathrm{aAB}} \\
\end{array}$ & $14.90 \pm 0.24^{\mathrm{aAB}}$ & $\begin{array}{l}13.37 \\
0.05^{\mathrm{bAB}} \\
\end{array}$ & $\begin{array}{l}14.92 \\
0.12^{\mathrm{aA}} \\
\end{array}$ & $\begin{array}{l}15.00 \\
0.38^{\mathrm{aAB}} \\
\end{array}$ \\
\hline & 14 & $\begin{array}{l}13.13 \\
0.23^{\mathrm{bBC}}\end{array}$ & $\begin{array}{l}14.82 \\
0.46^{\mathrm{aAB}}\end{array}$ & $14.90 \pm 0.34^{\mathrm{aAB}}$ & $\begin{array}{l}13.07 \\
0.26^{\mathrm{bAB}}\end{array}$ & $\begin{array}{l}14.68 \\
0.31^{\mathrm{aA}}\end{array}$ & $\begin{array}{l}14.83 \\
0.22^{\mathrm{aAB}}\end{array}$ \\
\hline & 21 & $\begin{array}{l}13.95 \\
1.41^{\mathrm{bAB}} \\
\end{array}$ & $\begin{array}{l}15.33 \\
1.13^{\mathrm{aAB}}\end{array}$ & $15.40 \pm 1.39^{\mathrm{aA}}$ & $\begin{array}{l}13.82 \\
1.01^{\mathrm{bA}} \\
\end{array}$ & $\begin{array}{l}15.20 \\
1.00^{\mathrm{aA}} \\
\end{array}$ & $15.28 \pm 0.93^{\mathrm{aA}}$ \\
\hline & 28 & $12.90 \pm 0.84^{\mathrm{bC}}$ & $14.47 \pm 0.68^{\mathrm{aB}}$ & $14.43 \pm 0.78^{\mathrm{aB}}$ & $\begin{array}{l}12.82 \\
0.66^{\mathrm{bB}}\end{array}$ & $\begin{array}{l}14.52 \\
0.58^{\mathrm{aA}}\end{array}$ & $14.25 \pm 0.85^{\mathrm{aB}}$ \\
\hline $\begin{array}{l}\text { Total } \\
\text { phenolic } \\
\text { compounds }\end{array}$ & 1 & $\begin{array}{l}1,791.32 \\
62.60^{\mathrm{aA}}\end{array} \quad \pm$ & $\begin{array}{l}1,490.48 \\
248.01^{\mathrm{aA}}\end{array} \quad \pm$ & $\begin{array}{l}1,867.86 \\
655.58^{\mathrm{aA}}\end{array}$ & $\begin{array}{l}1,679.67 \\
195.86^{\text {aA }}\end{array}$ & $\begin{array}{l}1780.52 \pm 114 \\
.23^{\mathrm{aAB}}\end{array}$ & $\begin{array}{l}1,835.44 \\
260.08^{\mathrm{aA}}\end{array}$ \\
\hline & 7 & $\begin{array}{ll}1,814.73 & \pm \\
521.63^{\mathrm{aA}} & \end{array}$ & $\begin{array}{ll}1,757.11 & \pm \\
109.39^{\mathrm{aA}} & \end{array}$ & $\begin{array}{l}1,628.35 \\
59.71^{\mathrm{aA}}\end{array}$ & $\begin{array}{l}1,926.38 \quad \pm \\
57.14^{\text {aA }}\end{array}$ & $\begin{array}{l}1720.19 \pm 140 \\
.07^{\mathrm{aAB}}\end{array}$ & $\begin{array}{l}2,006.52 \\
468.16^{\mathrm{aA}}\end{array}$ \\
\hline & 14 & $\begin{array}{ll}1,710.28 & \pm \\
545.33^{\mathrm{aA}} & \end{array}$ & $\begin{array}{ll}1,601.33 & \pm \\
168.41^{\mathrm{aA}} & \end{array}$ & $\begin{array}{l}1,609.44 \\
179.20^{\mathrm{aA}}\end{array}$ & $\begin{array}{l}1,729.19 \quad \pm \\
177.99^{\text {aA }}\end{array}$ & $\begin{array}{l}1,856.15 \quad \pm \\
146.55^{\mathrm{aA}}\end{array}$ & $\begin{array}{l}1,622.94 \\
170.96^{\mathrm{aA}}\end{array}$ \\
\hline & 21 & $\begin{array}{ll}1,599.53 & \pm \\
58.72^{\mathrm{aA}} & \\
\end{array}$ & $\begin{array}{l}1,843.55 \\
42.54^{\mathrm{aA}}\end{array}$ & $\begin{array}{l}1,719.29 \\
81.57^{\mathrm{aA}} \\
\end{array}$ & $\begin{array}{l}1,786.82 \quad \pm \\
35.30^{\mathrm{aA}}\end{array}$ & $\begin{array}{l}1,839.04 \quad \pm \\
58.33^{\mathrm{aAB}}\end{array}$ & $\begin{array}{l}1,880.46 \\
149.50^{\mathrm{aA}} \\
\end{array}$ \\
\hline & 28 & $\begin{array}{ll}1,678.77 & \pm \\
179.73^{\text {aA }} & \end{array}$ & $\begin{array}{l}1,651.76 \\
155.56^{\mathrm{aA}}\end{array}$ & $\begin{array}{ll}1,493.28 & \pm \\
265.78^{\mathrm{aA}} & \end{array}$ & $\begin{array}{ll}1,587.83 & \pm \\
213.48^{\mathrm{aA}} & \end{array}$ & $\begin{array}{ll}1,437.46 & \pm \\
341.71^{\mathrm{aB}} & \end{array}$ & $\begin{array}{l}1,700.38 \\
390.43^{\text {aA }}\end{array}$ \\
\hline
\end{tabular}

Means \pm standard deviation in the same line, followed by different lowercase letters indicate a significant difference $(\mathrm{p} \leq 0.05)$ between grape juice formulations for the same day of storage. Means \pm standard deviation in the same column, followed by different uppercase letters indicate a significant difference $(\mathrm{p} \leq 0.05)$ for each formulation affected by storage time $(n=6)$. Formulations: CONT (control), OLIG (oligofructose), POLY (polydextrose), PRO (probiotic), SYN-O (probiotic + oligofructose), and SYN-P (probiotic + polydextrose). Titratable acidity in $\%$ tartaric acid. Total soluble solids in ${ }^{\circ}$ Brix. Total phenolic compounds in mg EAG/L.

The results of the physicochemical characteristics suggest that the addition of probiotic cultures or prebiotic components do not have a negative impact on the $\mathrm{pH}$, acidity, and TSS values of the products and maintaining stability during storage similar to the control juice. The stability of the juice in relation to the physicochemical characteristics during storage is desirable, as it confirms that the products remain similar to the newly manufactured ones, even after a few weeks of storage [24].

The turbidity and color parameters of the grape juices are shown in Table 2 . The grape juices presented turbidity of 2.16-3.16, $\mathrm{L} *$ of $30.81-34.17$, a* of $0.13-2.24$, and $b^{*}$ of $0.17-0.67$, is characterized by a purple color.

The addition of the probiotic culture caused an increase in the turbidity and $\mathrm{a}^{*}$ and $\mathrm{b}^{*}$ values on day 1 of storage $(\mathrm{p}<0.05)$, suggesting that the probiotic products were more turbid, yellow, and red. The addition of the prebiotic compounds increased the * values of the products ( $p<0.05$ ), indicating that they became redder. The differences in the turbidity and color can be related to the addition of the freeze-dried probiotic culture and the prebiotic components in a powdered form. Grape juices are characterized by a non-turbid and purple juice; therefore, 
the increase in the turbidity, and the alterations in color could impact the sensory characteristics of the products, decreasing their acceptance.

Table 2. Turbidity and color parameters of the grape juice formulations.

\begin{tabular}{|c|c|c|c|c|c|c|c|}
\hline Parameter & $\begin{array}{l}\text { Storage time } \\
\text { (Days) }\end{array}$ & CONT & OLIG & POLY & PRO & SYN-O & SYN-P \\
\hline \multirow[t]{5}{*}{ Turbidity } & 1 & $2.26 \pm 0.19^{\mathrm{bC}}$ & $2.22 \pm 0.20^{\mathrm{bB}}$ & $2.16 \pm 0.19^{\mathrm{bB}}$ & $2.82 \pm 0.11^{\mathrm{aA}}$ & $2.84 \pm 0.11^{\mathrm{aA}}$ & $2.90 \pm 0.12^{\mathrm{aA}}$ \\
\hline & 7 & $\begin{array}{ll}3.04 & \pm \\
0.36^{\mathrm{aAB}} & \end{array}$ & $\begin{array}{ll}2.89 & \pm \\
0.58^{\mathrm{abA}} & \end{array}$ & $2.59 \pm 0.39^{\mathrm{bA}}$ & $\begin{array}{ll}2.98 & \pm \\
0.07^{\mathrm{abA}} & \end{array}$ & $3.06 \pm 0.18^{\mathrm{aA}}$ & $3.12 \pm 0.13^{\mathrm{aA}}$ \\
\hline & 14 & $2.74 \pm 0.06^{\mathrm{aB}}$ & $2.65 \pm 0.03^{\mathrm{aA}}$ & $2.67 \pm 0.12^{\mathrm{aA}}$ & $2.89 \pm 0.19^{\mathrm{aA}}$ & $2.99 \pm 0.28^{\mathrm{aA}}$ & $2.94 \pm 0.23^{\mathrm{aA}}$ \\
\hline & 21 & $\begin{array}{l}2.98 \\
0.16^{\mathrm{aAB}}\end{array}$ & $2.77 \pm 0.34^{\mathrm{aA}}$ & $2.78 \pm 0.25^{\mathrm{aA}}$ & $3.05 \pm 0.03^{\mathrm{aA}}$ & $3.05 \pm 0.06^{\mathrm{aA}}$ & $3.07 \pm 0.03^{\mathrm{aA}}$ \\
\hline & 28 & $3.16 \pm 0.33^{\mathrm{aA}}$ & $2.99 \pm 0.14^{\mathrm{aA}}$ & $2.88 \pm 0.33^{\mathrm{aA}}$ & $2.93 \pm 0.42^{\mathrm{aA}}$ & $3.13 \pm 0.33^{\mathrm{aA}}$ & $3.07 \pm 0.23^{\mathrm{aA}}$ \\
\hline \multirow[t]{5}{*}{$\mathrm{L}^{*}$} & 1 & $\begin{array}{ll}31.70 & \pm \\
0.29^{\mathrm{aAB}} & \end{array}$ & $\begin{array}{ll}31.77 & \pm \\
0.18^{\mathrm{aAB}} & \end{array}$ & $\begin{array}{ll}31.54 & \pm \\
0.59^{\mathrm{aAB}} & \end{array}$ & $\begin{array}{ll}31.32 & \pm \\
0.70^{\mathrm{aB}} & \end{array}$ & $\begin{array}{ll}31.88 & \pm \\
0.20^{\mathrm{aA}} & \end{array}$ & $31.72 \pm 0.41^{\mathrm{aA}}$ \\
\hline & 7 & $\begin{array}{ll}33.00 & \pm \\
2.64^{\text {abca }} & \end{array}$ & $\begin{array}{ll}33.28 & \pm \\
1.85^{\text {abA }} & \end{array}$ & $\begin{array}{ll}32.04 & \pm \\
1.07^{\text {bcAB }} & \end{array}$ & $\begin{array}{ll}34.17 & \pm \\
3.40^{\mathrm{aA}} & \end{array}$ & $\begin{array}{ll}31.51 & \pm \\
0.90^{\text {bca }} & \end{array}$ & $31.35 \pm 0.67^{\mathrm{cA}}$ \\
\hline & 14 & $\begin{array}{ll}30.88 & \pm \\
0.45^{\mathrm{aB}} & \\
\end{array}$ & $\begin{array}{ll}31.86 & \pm \\
0.74^{\mathrm{a} A \mathrm{~b}} & \end{array}$ & $\begin{array}{ll}32.58 & \pm \\
0.74^{\mathrm{aA}} & \\
\end{array}$ & $\begin{array}{ll}32.50 & \pm \\
1.37^{\mathrm{aB}} & \\
\end{array}$ & $\begin{array}{ll}32.02 & \pm \\
1.45^{\mathrm{aA}} & \end{array}$ & $31.90 \pm 0.80^{\mathrm{aA}}$ \\
\hline & 21 & $\begin{array}{ll}31.20 & \pm \\
0.43^{\mathrm{aB}} & \\
\end{array}$ & $\begin{array}{ll}31.18 & \pm \\
0.28^{\mathrm{aB}} & \\
\end{array}$ & $\begin{array}{ll}31.20 & \pm \\
0.11^{\mathrm{aAB}} & \\
\end{array}$ & $\begin{array}{ll}31.07 & \pm \\
0.17^{\mathrm{aB}} & \\
\end{array}$ & $\begin{array}{ll}31.51 & \pm \\
0.44^{\mathrm{aA}} & \\
\end{array}$ & $31.29 \pm 0.36^{\mathrm{aA}}$ \\
\hline & 28 & $\begin{array}{ll}31.01 & \pm \\
0.09^{\mathrm{aB}} & \\
\end{array}$ & $\begin{array}{ll}31.36 & \pm \\
0.49^{\mathrm{aB}} & \\
\end{array}$ & $\begin{array}{ll}30.81 & \pm \\
0.17^{\mathrm{aB}} & \\
\end{array}$ & $\begin{array}{ll}30.92 & \pm \\
0.10^{\mathrm{aB}} & \\
\end{array}$ & $\begin{array}{l}31.13 \\
0.21^{\mathrm{aA}} \\
\end{array}$ & $30.88 \pm 0.52^{\mathrm{aA}}$ \\
\hline \multirow[t]{5}{*}{$a^{*}$} & 1 & $0.18 \pm 0.02^{\mathrm{cA}}$ & $1.54 \pm 0.73^{\mathrm{bA}}$ & $2.24 \pm 0.65^{\mathrm{aA}}$ & $\begin{array}{ll}1.80 & \pm \\
0.72^{\mathrm{abA}} & \\
\end{array}$ & $\begin{array}{ll}1.93 & \pm \\
0.51^{\mathrm{abA}} & \\
\end{array}$ & $1.72 \pm 0.35^{\mathrm{abA}}$ \\
\hline & 7 & $0.13 \pm 0.01^{\mathrm{dA}}$ & $\begin{array}{ll}0.98 & \pm \\
0.02^{\mathrm{abA}} & \\
\end{array}$ & $1.48 \pm 0.21^{\mathrm{aB}}$ & \begin{tabular}{ll|}
0.85 & \pm \\
$0.08^{\mathrm{bcB}}$ & \\
\end{tabular} & $\begin{array}{ll}0.61 & \pm \\
0.09^{\text {bcdB }} & \\
\end{array}$ & $0.31 \pm 0.01^{\mathrm{cdB}}$ \\
\hline & 14 & $0.33 \pm 0.05^{\mathrm{aA}}$ & $0.28 \pm 0.08^{\mathrm{aB}}$ & $0.19 \pm 0.04^{\mathrm{aC}}$ & $\begin{array}{ll}0.30 & \pm \\
0.03^{\mathrm{aBC}} & \\
\end{array}$ & $0.51 \pm 0.09^{\mathrm{aB}}$ & $0.42 \pm 0.11^{\mathrm{aB}}$ \\
\hline & 21 & $0.19 \pm 0.04^{\mathrm{aA}}$ & $0.27 \pm 0.05^{\mathrm{aB}}$ & $0.46 \pm 0.03^{\mathrm{aC}}$ & $\begin{array}{l}0.28 \quad \pm \\
0.01^{\mathrm{aBC}}\end{array}$ & $0.27 \pm 0.03^{\mathrm{aB}}$ & $0.20 \pm 0.05^{\mathrm{aB}}$ \\
\hline & 28 & $0.20 \pm 0.06^{\mathrm{aA}}$ & $0.16 \pm 0.02^{\mathrm{aB}}$ & $0.27 \pm 0.04^{\mathrm{aC}}$ & $0.19 \pm 0.03^{\mathrm{aC}}$ & $0.23 \pm 0.03^{\mathrm{aB}}$ & $0.19 \pm 0.02^{\mathrm{aB}}$ \\
\hline \multirow[t]{5}{*}{$b^{*}$} & 1 & $0.40 \pm 0.06^{\mathrm{bB}}$ & $0.43 \pm 0.10^{\mathrm{bA}}$ & $\begin{array}{ll}0.44 & \pm \\
0.07^{\mathrm{bAB}} & \\
\end{array}$ & $0.60 \pm 0.07^{\mathrm{aA}}$ & $\begin{array}{ll}0.42 & \pm \\
0.16^{\mathrm{bC}} & \end{array}$ & $0.40 \pm 0.06^{\mathrm{bBC}}$ \\
\hline & 7 & $0.40 \pm 0.04^{\mathrm{bB}}$ & $\begin{array}{ll}0.24 & \pm \\
0.03^{\mathrm{cBC}} & \\
\end{array}$ & $\begin{array}{ll}0.32 & \pm \\
0.03^{\text {bcC }} & \end{array}$ & $0.30 \pm 0.02^{\mathrm{bcC}}$ & $\begin{array}{l}0.55 \\
0.05^{\mathrm{aAB}}\end{array}$ & $0.67 \pm 0.01^{\mathrm{aA}}$ \\
\hline & 14 & $\begin{array}{ll}0.48 & \pm \\
0.03^{\mathrm{aAB}} & \end{array}$ & $0.30 \pm 0.05^{\mathrm{bB}}$ & $0.32 \pm 0.07^{\mathrm{bC}}$ & $0.47 \pm 0.04^{\mathrm{aB}}$ & $\begin{array}{l}0.58 \\
0.08^{\mathrm{aA}} \\
\end{array}$ & $0.31 \pm 0.04^{\mathrm{bC}}$ \\
\hline & 21 & $\begin{array}{l}0.48 \quad \pm \\
0.02^{\mathrm{aAB}}\end{array}$ & $0.17 \pm 0.02^{\mathrm{cC}}$ & $\begin{array}{l}0.38 \quad \pm \\
0.02^{\text {abBC }}\end{array}$ & $0.44 \pm 0.01^{\mathrm{aB}}$ & $\begin{array}{l}0.43 \quad \pm \\
0.04^{\mathrm{abC}}\end{array}$ & $0.30 \pm 0.01^{\mathrm{bcC}}$ \\
\hline & 28 & $0.53 \pm 0.02^{\mathrm{aA}}$ & $\begin{array}{ll}0.24 & \pm \\
0.03^{\mathrm{BBC}} & \end{array}$ & $0.54 \pm 0.04^{\mathrm{aA}}$ & $0.50 \pm 0.06^{\mathrm{aAB}}$ & $\begin{array}{ll}0.45 & \pm \\
0.04^{\mathrm{aBC}} & \end{array}$ & $0.44 \pm 0.03^{\mathrm{aB}}$ \\
\hline
\end{tabular}

Means \pm standard deviation in the same line, followed by different lowercase letters indicate a significant difference $(p \leq 0.05)$ between grape juice formulations for the same day of storage. Means \pm standard deviation in the same column, followed by different uppercase letters indicate a significant difference $(p \leq 0.05)$ for each formulation affected by storage time $(\mathrm{n}=6)$. Formulations: CONT (control), OLIG (oligofructose), POLY (polydextrose), PRO (probiotic), SYN-O (probiotic + oligofructose), and SYN-P (probiotic + polydextrose). L* ranging from 0 (black) to 100 (white), $a^{*}$ ranging from red $\left(+a^{*}\right)$ to green $\left(-a^{*}\right)$ and $b^{*}$ ranging from yellow $\left(+b^{*}\right)$ to blue (-b*). Turbidity at $600 \mathrm{~nm}$.

During storage, there was an increase in the turbidity of the control, prebiotic and synbiotic formulations $(\mathrm{p}<0.05)$, while maintenance in this parameter was observed for the probiotic formulation ( $\mathrm{p}>0.05$, comparing days 1 and 28). The increase in the turbidity can be caused by components of the grape or the prebiotic components that were suspended and formed flakes during the storage, causing turbidity [34]. Although the probiotic formulation had increased initial turbidity, the stability of this parameter was higher in this formulation.

For color parameters, there was the maintenance of the $L^{*}$ values $(p>0.05)$ during storage for all formulations (comparing the products on days 1 and 28 of storage). For a* values, the probiotic and prebiotic added formulations presented lower values $(p<0.05)$, suggesting that they originated products with a lower red color. Finally, for $b^{*}$ values, the control formulation had increased values, oligofructose had decreased values $(p<0.05)$, and the other formulations maintained the values. Color stability is an important characteristic of 
the acceptance of the products by consumers since the color is one of the primary attributes of quality [24]. The maintenance of the $\mathrm{L}^{*}$ values during storage indicates that the probiotic cultures survived during refrigerated storage, as the accumulation of lysed or dead bacterial cells is related to darker products [28].

It is recommended the consumption of $2-4 \mathrm{~g} /$ day of the prebiotic components $[25,26]$. The grape juices of the present study were added with $20 \mathrm{~g} / \mathrm{L}$ of oligofructose or polydextrose; therefore, the recommended dosage could be achieved with daily consumption of 100-200 mL. Although the quantification of the prebiotics during storage was not performed, previous studies $[13,16]$ reported that there are no significant losses $(<10 \%)$ during the processing and storage of fruit juices.

\subsection{Texture properties.}

The texture parameters are shown in Table 3. The juices had a firmness of 26.42-36.82 $\mathrm{g}$, consistency of 152.81-234.04 g sec, a viscosity index of 0.76-1.05 g sec, and cohesiveness of 5.97-7.37. There was no effect of the addition of the probiotic culture or prebiotic components on the texture parameters of the grape juices $(p>0.05)$. Grape juices are characterized as liquid and homogeneous products; therefore, the maintenance of the texture parameters after the addition of the probiotic cultures and prebiotic components is interesting from the commercialization point of view $[13,17,20]$.

During storage, all formulations behaved similarly, with the maintenance of the cohesiveness and viscosity index $\left(\mathrm{p}>0.05\right.$, comparing the products on the $1^{\text {st }}$ and $28^{\text {th }}$ of storage) and decreases in the firmness and consistency values $(\mathrm{p}<0.05)$. The decrease in the firmness and consistency parameters may be related to the interactions among particles of the juices, resulting in some aggregation and consequent precipitation [20]. Furthermore, it may be associated with the precipitation of potassium bitartrate, which occurs easily due to the large amount present in the juice [34].

\subsection{Probiotic survival.}

The L. casei survival during storage is shown in Figure 1. On the first day of storage, all the grape juice formulations presented similar probiotic counts $(p>0.05)$, suggesting that the probiotic counts were added at the same concentration.

The addition of the prebiotic components (oligofructose or polydextrose) did not impact the probiotic viability $(\mathrm{p}>0.05)$. The absence of the protective effect of the prebiotics on the viability of the probiotic cultures can be related to the suitability of the grape juice as a carrier for the probiotic culture. Prebiotic components have the ability to increase the viability of probiotics in fruit juices that present a hostile environment [13]. Grape juices, although presenting a very low $\mathrm{pH}$ (2.88-3.18), have phenolic compounds (are antioxidants) and high acid concentration (which can be metabolized by the probiotic culture), which could have helped to maintain the L. casei counts [14,20,33]. Furthermore, grape juice presents vitamin C, which can contribute to reducing the dissolved oxygen, increasing probiotic survival [13,35].

During the storage period, the probiotic counts were maintained in all formulations ( $p$ $>0.05$ ), and the viability remained higher than $10^{6} \mathrm{CFU} / \mathrm{mL}$, which is higher than the minimum $\left(10^{6} \mathrm{CFU} / \mathrm{mL}\right)$ suggested considering a product as probiotic $[13,16]$. Thus, all juices added with $L$. casei could be considered probiotic products during the 28 days of refrigerated storage. The results suggest that grape juice is a suitable carrier for probiotic cultures, and the products 
could be stored for 28 days at $7{ }^{\circ} \mathrm{C}$ in PET flasks, which is the conventional condition of commercialization of pasteurized juices. In addition, it proves the viability of including freezedried probiotic cultures into juices, resulting in products with adequate probiotic counts. This result is particularly important for the juice industry since it results in an easier and timeconsuming production.

Table 3. Texture parameters of the grape juice formulations.

\begin{tabular}{|c|c|c|c|c|c|c|c|}
\hline Parameter & $\begin{array}{l}\text { Storage } \\
\text { time (Days) }\end{array}$ & CONT & OLIG & POLY & PRO & SYN-O & SYN-P \\
\hline \multirow[t]{5}{*}{ Firmness } & 1 & $\begin{array}{ll}35.52 & \pm \\
10.16^{\mathrm{aA}} & \\
\end{array}$ & $\begin{array}{ll}36.30 & \pm \\
9.93^{\mathrm{aA}} & \\
\end{array}$ & $\begin{array}{ll}36.29 & \pm \\
9.15^{\mathrm{aA}} & \\
\end{array}$ & \begin{tabular}{ll|}
35.87 & \pm \\
$9.66^{\mathrm{aA}}$ & \\
\end{tabular} & $\begin{array}{ll}36.82 & \pm \\
10.39^{\mathrm{aA}} & \\
\end{array}$ & $36.77 \pm 9.91^{\mathrm{aA}}$ \\
\hline & 7 & $32.03 \pm 4.68^{\mathrm{aAB}}$ & $\begin{array}{ll}31.86 & \pm \\
4.44^{\mathrm{aAB}} & \\
\end{array}$ & $\begin{array}{ll}32.26 & \pm \\
5.26^{\mathrm{aAB}} & \\
\end{array}$ & $\begin{array}{|ll|}32.10 & \pm \\
4.9^{2 \mathrm{aAB}} & \\
\end{array}$ & $\begin{array}{l}31.92 \\
4.61^{\mathrm{aAB}}\end{array}$ & $\begin{array}{ll}31.72 & \pm \\
4.15^{\mathrm{aAB}} & \\
\end{array}$ \\
\hline & 14 & $26.47 \pm 0.99^{\mathrm{aB}}$ & $\begin{array}{l}27.00 \\
1.28^{\mathrm{aB}}\end{array}$ & $\begin{array}{l}27.09 \\
0.38^{\mathrm{aB}}\end{array}$ & $\begin{array}{ll}26.42 & \pm \\
0.65^{\mathrm{aB}} & \\
\end{array}$ & $\begin{array}{l}26.75 \\
1.20^{\mathrm{aB}}\end{array}$ & $26.78 \pm 0.80^{\mathrm{aB}}$ \\
\hline & 21 & $27.93 \pm 0.66^{\mathrm{aB}}$ & $\begin{array}{ll}28.85 & \pm \\
0.47^{\mathrm{aB}} & \\
\end{array}$ & $\begin{array}{ll}28.68 & \pm \\
0.85^{\mathrm{aB}} & \\
\end{array}$ & $\begin{array}{ll}28.42 & \pm \\
0.70^{\mathrm{aB}} & \\
\end{array}$ & $\begin{array}{l}28.05 \\
2.31^{\mathrm{aB}} \\
\end{array}$ & $28.50 \pm 1.26^{\mathrm{aB}}$ \\
\hline & 28 & $27.83 \pm 0.22^{\mathrm{aB}}$ & $\begin{array}{ll}27.92 & \pm \\
0.31^{\mathrm{aB}} & \\
\end{array}$ & $\begin{array}{ll}27.69 & \pm \\
0.46^{\mathrm{aB}} & \\
\end{array}$ & $\begin{array}{ll}27.90 & \pm \\
0.43^{\mathrm{aB}} & \\
\end{array}$ & $\begin{array}{l}28.37 \\
0.18^{\mathrm{aB}} \\
\end{array}$ & $27.78 \pm 0.32^{\mathrm{aB}}$ \\
\hline \multirow[t]{5}{*}{ Consistency } & 1 & $\begin{array}{ll}226.58 & \pm \\
83.38^{\mathrm{aA}} & \end{array}$ & $\begin{array}{l}229.27 \\
82.86^{\mathrm{aA}} \\
\end{array}$ & $\begin{array}{ll}228.65 & \pm \\
76.30^{\mathrm{aA}} & \\
\end{array}$ & $\begin{array}{l}228.94 \\
79.53^{\mathrm{aA}} \\
\end{array}$ & $\begin{array}{l}231.24 \\
81.41^{\mathrm{aA}} \\
\end{array}$ & $\begin{array}{ll}234.04 & \pm \\
80.03^{\mathrm{aA}} & \\
\end{array}$ \\
\hline & 7 & $\begin{array}{ll}182.52 & \pm \\
24.74^{\mathrm{aAB}} & \end{array}$ & $\begin{array}{ll}181.34 & \pm \\
23.92^{\mathrm{aAB}} & \\
\end{array}$ & $\begin{array}{ll}185.89 & \pm \\
28.67^{\mathrm{aAB}} & \\
\end{array}$ & $\begin{array}{ll}186.12 & \pm \\
28.27^{\mathrm{aAB}} & \\
\end{array}$ & $\begin{array}{ll}184.26 & \pm \\
26.10^{\mathrm{aAB}} & \\
\end{array}$ & $\begin{array}{ll}181.31 & \pm \\
22.59^{\mathrm{aAB}} & \\
\end{array}$ \\
\hline & 14 & $151.71 \pm 6.24^{\mathrm{aB}}$ & $\begin{array}{ll}154.43 & \pm \\
7.42^{\mathrm{aB}} & \\
\end{array}$ & $\begin{array}{ll}156.47 & \pm \\
6.51^{\mathrm{aB}} & \end{array}$ & $\begin{array}{ll}152.81 & \pm \\
4.64^{\mathrm{aB}} & \\
\end{array}$ & $\begin{array}{l}155.53 \\
8.28^{\mathrm{aB}}\end{array}$ & $\begin{array}{l}155.19 \\
6.43^{\mathrm{aB}}\end{array}$ \\
\hline & 21 & $161.61 \pm 2.40^{\mathrm{aB}}$ & $\begin{array}{ll}166.40 & \pm \\
4.40^{\mathrm{aB}} & \\
\end{array}$ & $\begin{array}{ll}167.05 & \pm \\
6.58^{\mathrm{aB}} & \\
\end{array}$ & $\begin{array}{ll}163.35 & \pm \\
4.74^{\mathrm{aB}} & \\
\end{array}$ & $\begin{array}{l}159.40 \\
20.73^{\mathrm{aB}}\end{array}$ & $\begin{array}{l}165.34 \\
7.42^{\mathrm{aB}} \\
\end{array}$ \\
\hline & 28 & $160.02 \pm 2.45^{\mathrm{aB}}$ & $\begin{array}{ll}160.91 & \pm \\
3.37^{\mathrm{aB}} & \\
\end{array}$ & $\begin{array}{ll}159.74 & \pm \\
4.14^{\mathrm{aB}} & \\
\end{array}$ & $\begin{array}{ll}161.11 & \pm \\
2.80^{\mathrm{aB}} & \\
\end{array}$ & $\begin{array}{l}163.42 \\
3.13^{\mathrm{aB}} \\
\end{array}$ & $\begin{array}{l}160.92 \\
2.53^{\mathrm{aB}} \\
\end{array}$ \\
\hline \multirow[t]{5}{*}{ Cohesiveness } & 1 & $7.13 \pm 1.73^{\mathrm{aA}}$ & $7.17 \pm 1.45^{\mathrm{aA}}$ & $7.37 \pm 1.36^{\mathrm{aB}}$ & $7.24 \pm 1.18^{\mathrm{aA}}$ & $\begin{array}{ll}7.32 & \pm \\
1.27^{\mathrm{aAB}} & \end{array}$ & $7.08 \pm 1.41^{\mathrm{aA}}$ \\
\hline & 7 & $7.18 \pm 1.19^{\mathrm{aA}}$ & $\begin{array}{ll}7.08 & \pm \\
1.30 \mathrm{aA} & \\
\end{array}$ & $7.44 \pm 1.18^{\mathrm{aB}}$ & $7.26 \pm 1.3^{2 \mathrm{aA}}$ & $7.43 \pm 1.42^{\mathrm{aB}}$ & $7.18 \pm 1.18^{\mathrm{aA}}$ \\
\hline & 14 & $6.18 \pm 0.28^{\mathrm{aA}}$ & $6.10 \pm 0.46^{\mathrm{aA}}$ & $\begin{array}{ll}6.21 & \pm \\
0.18^{\mathrm{aAB}} & \end{array}$ & $6.20 \pm 0.25^{\mathrm{aA}}$ & $6.12 \pm 0.29^{\mathrm{aA}}$ & $6.01 \pm 0.38^{\mathrm{aA}}$ \\
\hline & 21 & $6.21 \pm 0.42^{\mathrm{aA}}$ & $6.12 \pm 0.22^{\mathrm{aA}}$ & $6.10 \pm 0.23^{\mathrm{aA}}$ & $6.20 \pm 0.18^{\mathrm{aA}}$ & $6.16 \pm 0.21^{\mathrm{aA}}$ & $6.20 \pm 0.16^{\mathrm{aA}}$ \\
\hline & 28 & $5.97 \pm 0.26^{\mathrm{aA}}$ & $6.23 \pm 0.15^{\mathrm{aA}}$ & $\begin{array}{ll}6.27 & \pm \\
0.13^{\mathrm{aAB}} & \end{array}$ & $6.18 \pm 0.36^{\mathrm{aA}}$ & $6.29 \pm 0.20^{\mathrm{aA}}$ & $6.43 \pm 0.28^{\mathrm{aA}}$ \\
\hline \multirow[t]{5}{*}{ Viscosity index } & 1 & $0.88 \pm 0.28^{\mathrm{aA}}$ & $\begin{array}{cc}0.99 & \pm \\
0.24^{\mathrm{aA}} & \\
\end{array}$ & $\begin{array}{ll}0.97 & \pm \\
0.21^{\mathrm{aAB}} & \\
\end{array}$ & $\begin{array}{ll}1.044 & \pm \\
0.21^{\mathrm{aA}} & \\
\end{array}$ & $\begin{array}{ll}1.03 & \pm \\
0.21^{\mathrm{aA}} & \\
\end{array}$ & $0.93 \pm 0.18^{\mathrm{aAB}}$ \\
\hline & 7 & $0.82 \pm 0.27^{\mathrm{aA}}$ & $\begin{array}{ll}1.00 & \pm \\
0.27^{\mathrm{abA}} & \\
\end{array}$ & $1.18 \pm 0.28^{\mathrm{bB}}$ & $0.98 \pm 0.29^{\mathrm{abA}}$ & $\begin{array}{ll}1.02 & \pm \\
0.25^{\mathrm{abA}} & \\
\end{array}$ & $1.05 \pm 0.22^{\mathrm{abB}}$ \\
\hline & 14 & $0.93 \pm 0.13^{\mathrm{aA}}$ & $0.85 \pm 0.12^{\mathrm{aA}}$ & $\begin{array}{ll}0.97 & \pm \\
0.11^{\mathrm{aAB}} & \\
\end{array}$ & $0.99 \pm 0.09^{\mathrm{aA}}$ & $\begin{array}{ll}0.83 & \pm \\
0.11^{\mathrm{aA}} & \\
\end{array}$ & $0.80 \pm 0.14^{\mathrm{aAB}}$ \\
\hline & 21 & $0.80 \pm 0.09^{\mathrm{aA}}$ & $0.74 \pm 0.07^{\mathrm{aA}}$ & $0.78 \pm 0.08^{\mathrm{aA}}$ & $0.79 \pm 0.10^{\mathrm{aA}}$ & $\begin{array}{ll}0.77 & \pm \\
0.12^{\mathrm{aA}} & \\
\end{array}$ & $0.76 \pm 0.10^{\mathrm{aA}}$ \\
\hline & 28 & $0.81 \pm 0.09^{\mathrm{aA}}$ & $0.93 \pm 0.17^{\mathrm{aA}}$ & $0.85 \pm 0.09^{\mathrm{aA}}$ & $0.88 \pm 0.11^{\mathrm{aA}}$ & $\begin{array}{ll}0.85 & \pm \\
0.15^{\mathrm{aA}} & \end{array}$ & $0.88 \pm 0.15^{\mathrm{aAB}}$ \\
\hline
\end{tabular}

Means \pm standard deviation in the same line, followed by different lowercase letters indicate a significant difference $(p \leq 0.05)$ between grape juice formulations for the same day of storage. Means \pm standard deviation in the same column, followed by different uppercase letters indicate a significant difference $(p \leq 0.05)$ for each formulation affected by storage time $(\mathrm{n}=6)$. Formulations: CONT (control), OLIG (oligofructose), POLY (polydextrose), PRO (probiotic), SYN-O (probiotic + oligofructose), and SYN-P (probiotic + polydextrose). Firmness in g, consistency in g sec, viscosity index in g sec, cohesiveness dimensionless.

\subsection{Sensory acceptance.}

Table 4 presents the acceptance scores (appearance, aroma, flavor, texture, and overall impression) and purchase intention of the grape juices. The grape juice formulations received scores from 6.09 to 8.28 in the assessed attributes, suggesting that the consumers liked slightly too much the products. Furthermore, they received scores of 3.02-4.43 for the purchase intention, indicating that the consumers probably would buy the products. Finally, the grape 
juices presented acceptance indices of $71-90 \%$, which is higher than the suggested to consider a product as potential to be commercialized (> 70\%, [31]).

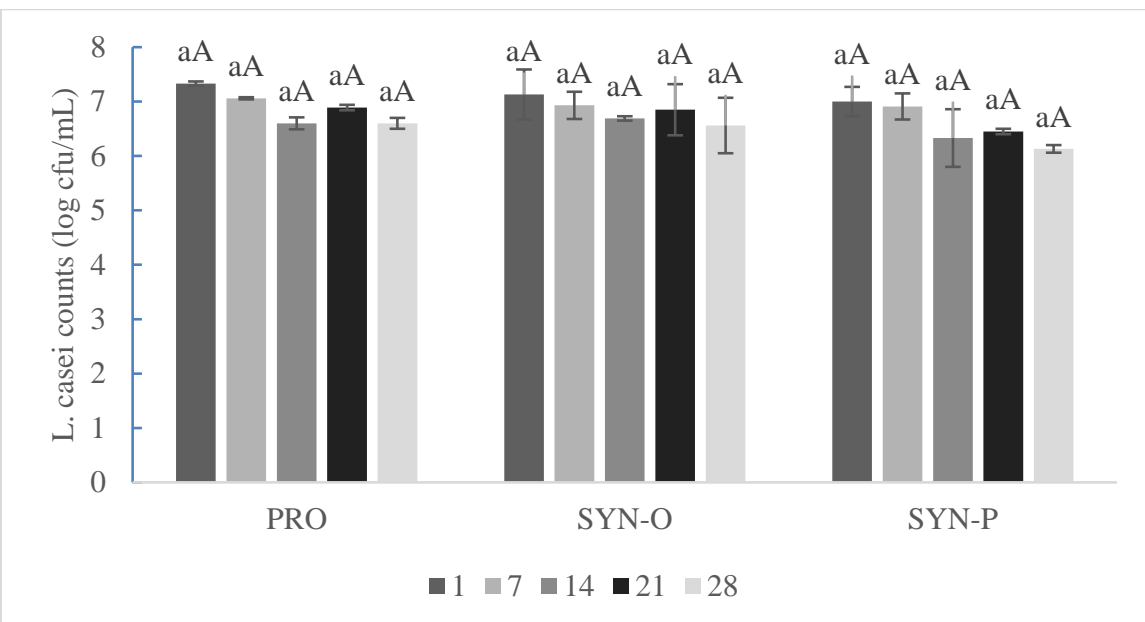

Figure 1. Viability ( $\log \mathrm{CFU} / \mathrm{mL})$ of the Lacticaseibacillus casei in grape juice formulations during refrigerated storage $\left(7^{\circ} \mathrm{C}\right)$. The error bars represent the standard deviation $(n=6)$. Different lowercase letters indicate statistically significant differences at $\mathrm{p} \leq 0.05$ between formulations for the same storage day, and different uppercase letters indicate statistically significant differences at $\mathrm{p} \leq 0.05$ for each formulation affected by storage time. Days of storage: 1, 7, 14, 21, and 28. Formulations: PRO (probiotic), SYN-O (probiotic + oligofructose), and SYN-P (probiotic + polydextrose).

The addition of oligofructose (OLIG) did not interfere $(\mathrm{p}>0.05)$ in the acceptance (appearance, aroma, flavor, texture, and overall impression) of the grape juices. This result corroborates those observed for the physicochemical characteristics, color parameters, and texture properties (Tables 1 and 2), as the addition of oligofructose maintained all the characteristics similar to the control juice ( $p>0.05$, except turbidity and TSS).

The addition of polydextrose (POLY) reduced the acceptance of the products on the flavor, texture, and overall impression, and also the purchase intention $(\mathrm{p}<0.05)$. The consumers reported the presence of particles in this formulation, which impacted negatively on the flavor and texture acceptance, and, consequently, on the overall impression. Although no differences were observed between the POLY and CONT formulations on the physicochemical and texture parameters (Tables 1 and 2, except $a^{*}$ values), the consumers were able to identify the presence of particles. Polydextrose has a solubility of $80 \%$ at $25{ }^{\circ} \mathrm{C}$ [36]. The prebiotic component was added to the product at refrigerated temperature; therefore, the insoluble part was identified by consumers. One alternative to preclude this negative impact would be adding the prebiotic component before the pasteurization process of the juices, as the solubility increases with the temperature. However, should be evaluated the losses with the heating treatment.

The addition of the probiotic culture (PRO) caused a decrease in the acceptance of the products in the aroma, flavor, texture, and overall impression, as well as in the purchase intention $(\mathrm{p} \leq 0.05)$. Only the acceptance in the appearance was maintained $(\mathrm{p}>0.05)$. The consumers reported high acidity, off-flavor, non-characteristic aroma, and the presence of particles in this formulation, which impacted negatively on the aroma, flavor, and texture acceptance, and, consequently, on the overall impression. However, no differences were observed between the PRO and CONT formulations on the physicochemical and texture parameters (Tables 1 and 2, except turbidity, $a^{*}$, and $b^{*}$ ), the consumers were able to identify differences. The higher acidity observed could be attributed to the presence of different organic 
acids. Miranda et al. [17] observed no effect of the addition of probiotic cultures in the $\mathrm{pH}$ of orange juices; however, the products with probiotics in the freeze-dried form presented lower citric acid content and higher acetic and lactic acid contents. Lactic acid can cause a flavor of dairy products in fruit juices [17], while the presence of acetic acid is associated with a pungent and vinegar taste [37]. Pimentel et al. [24] reported that the consumers elicited acid aftertaste and altered flavor as characteristics of the probiotic peach nectars.

Table 4. Sensory acceptance of the grape juice formulations.

\begin{tabular}{|c|c|c|c|c|c|c|c|}
\hline Parameter & Appearance & Aroma & Flavor & Texture & $\begin{array}{l}\text { Overall } \\
\text { impression }\end{array}$ & $\begin{array}{l}\text { Purchase } \\
\text { intention }\end{array}$ & $\begin{array}{l}\text { Acceptability } \\
\text { index }(\%)\end{array}$ \\
\hline CONT & $8.28 \pm 1.12^{\mathrm{A}}$ & $\begin{array}{ll}7.93 & \pm \\
1.31^{\mathrm{A}} & \\
\end{array}$ & \begin{tabular}{ll|}
7.84 & \pm \\
$1.36^{\mathrm{A}}$ & \\
\end{tabular} & $\begin{array}{ll}8.02 & \pm \\
1.17^{\mathrm{AB}} & \\
\end{array}$ & $\begin{array}{ll}8.08 & \pm \\
1.17^{\mathrm{A}} & \\
\end{array}$ & $\begin{array}{ll}4.43 & \pm \\
0.88^{\mathrm{A}} & \\
\end{array}$ & 90 \\
\hline OLIG & $8.24 \pm 1.09^{\mathrm{A}}$ & $\begin{array}{ll}7.51 & \pm \\
1.50^{\mathrm{AB}} & \end{array}$ & $\begin{array}{ll}7.63 & \pm \\
1.49^{\mathrm{A}} & \\
\end{array}$ & $\begin{array}{ll}8.09 & \pm \\
1.05^{\mathrm{A}} & \end{array}$ & $\begin{array}{ll}7.93 & \pm \\
1.19^{\mathrm{AB}} & \end{array}$ & $\begin{array}{ll}4.11 & \pm \\
0.93^{\mathrm{AB}} & \end{array}$ & 88 \\
\hline POLY & $8.07 \pm 1.14^{\mathrm{A}}$ & $\begin{array}{ll}7.27 & \pm \\
1.71^{\mathrm{AB}} & \\
\end{array}$ & $\begin{array}{|ll|}6.63 & \pm \\
2.08^{\mathrm{BC}} & \\
\end{array}$ & $\begin{array}{ll}7.44 & \pm \\
1.61^{\mathrm{ABC}} & \end{array}$ & $\begin{array}{ll}7.18 & \pm \\
1.61^{\mathrm{C}} & \\
\end{array}$ & $\begin{array}{ll}3.47 & \pm \\
1.10^{\mathrm{CD}} & \end{array}$ & 80 \\
\hline PRO & $7.70 \pm 1.51^{\mathrm{A}}$ & $\begin{array}{ll}7.11 & \pm \\
1.74^{\mathrm{B}} & \end{array}$ & $\begin{array}{ll}6.86 & \pm \\
1.82^{\mathrm{B}} & \end{array}$ & $\begin{array}{ll}6.90 & \pm \\
1.80^{\mathrm{CD}} & \end{array}$ & $\begin{array}{l}7.06 \\
1.66^{\mathrm{C}}\end{array}$ & $\begin{array}{ll}3.44 & \pm \\
1.15^{\mathrm{CD}} & \end{array}$ & 78 \\
\hline SYNB-O & $7.71 \pm 1.33^{\mathrm{A}}$ & $\begin{array}{ll}7.46 & \pm \\
1.34^{\mathrm{AB}} & \\
\end{array}$ & $\begin{array}{ll}7.24 & \pm \\
1.47^{\mathrm{AB}} & \\
\end{array}$ & $\begin{array}{ll}7.36 & \pm \\
1.58^{\mathrm{BC}} & \\
\end{array}$ & $\begin{array}{ll}7.37 & \pm \\
1.36^{\mathrm{BC}} & \\
\end{array}$ & $\begin{array}{ll}3.76 & \pm \\
1.02^{\mathrm{BC}} & \\
\end{array}$ & 82 \\
\hline SYNB-P & $7.06 \pm 2.05^{\mathrm{B}}$ & $\begin{array}{ll}7.02 & \pm \\
1.67^{\mathrm{B}} & \end{array}$ & $\begin{array}{ll}6.09 & \pm \\
2.12^{\mathrm{C}} & \end{array}$ & $\begin{array}{ll}6.57 & \pm \\
2.09^{\mathrm{D}} & \end{array}$ & $\begin{array}{ll}6.37 & \pm \\
1.95^{\mathrm{D}} & \end{array}$ & $\begin{array}{ll}3.02 & \pm \\
1.23^{\mathrm{D}} & \end{array}$ & 71 \\
\hline
\end{tabular}

Means \pm standard deviation on the same column with different letters indicates differences at $\mathrm{p} \leq 0.05$. Formulations: CONT (control), OLIG (oligofructose), POLY (polydextrose), PRO (probiotic), SYN-O (probiotic + oligofructose), and SYN-P (probiotic + polydextrose). Hedonic values (appearance, aroma, flavor, texture, and overall impression): 1 - liked extremely, 9 - disliked extremely. Purchase intention values: $1=$ certainly would not buy, 5 = certainly would buy. Acceptability index, according to Dutcocky [31].

The probiotic products probably presented a lower number of compounds that contribute to the typical grape juice aroma, as well as, the probiotic cultures could have formed other non-desired compounds. Miranda et al. [17] reported that the addition of probiotic cultures could impact the aroma profile of the products, is not observed important compounds associated with the typical fruity, grassy, and green aromas. Furthermore, there were compounds associated with a moldy, pungent aroma, oxidized taste, and fat aroma, which were not observed in the control juice. Concerning the texture, the probiotic culture was added to the product at refrigerated temperature and in freeze-dried form; therefore, it could be identified by consumers. One alternative to preclude this negative impact would be adding the probiotic culture after the pasteurization process of the juices but at warm temperatures $\left(37^{\circ} \mathrm{C}\right)$, aiming for better solubilization in the medium.

The addition of oligofructose to the probiotic product (SYN-O) caused an improvement in the acceptance of the probiotic product (PRO) in the aroma, flavor, and texture attributes, making it similar $(\mathrm{p}>0.05)$ to that of the pure product. However, the juice with oligofructose was still less accepted than the control in the overall impression $(p \leq 0.05)$. The probiotic culture could have metabolized part of the oligofructose, resulting in the formation of aroma compounds important for the grape juices. Furthermore, the presence of the oligofructose could have masked the off-flavor observed in the product added with probiotic cultures. This is because oligofructose has properties comparable to sucrose and glucose due to the presence of free sugars in its composition, resulting in a sweetness power of about $30-60 \%$ of the observed for sucrose [16].

The addition of polydextrose (SYN-P) to the probiotic product, in addition to the changes reported for the probiotic product, caused a decrease in the acceptance in the appearance and aroma $(\mathrm{p} \leq 0.05)$, making this formulation the least accepted one. The decrease 
in the appearance could be related to the increase in the turbidity promoted by the probiotic culture (Table 1). The probiotic culture could have metabolized part of the polydextrose, resulting in the formation of aroma compounds that negatively contributed to the aroma of the grape juices.

The results of the present study suggest that consumers are able to identify differences in the products that could not be observed in physical and chemical evaluations. It is important to mention that all formulations were scored in at least as "liked slightly", suggesting that the addition of probiotic cultures and prebiotic components to grape juices is possible. It is advisable to include the prebiotic components before the pasteurization step and the probiotic cultures with the juice at a warm temperature, therefore, helping in their solubilization in the medium. The SYN-O and SYN-P formulations could be considered potentially synbiotic products, as they present and established probiotic + established prebiotic [38].

\section{Conclusions}

This study proved that it is possible to produce potentially synbiotic grape juices with suitable physicochemical characteristics, color parameters, texture properties, probiotic survival, and sensory acceptance by adding L. casei as probiotic and oligofructose or polydextrose as prebiotic components. The grape juices presented scores higher than 6 on a 9point hedonic scale and acceptability index higher than $70 \%$, as well as the probiotic viability higher than $10^{6} \mathrm{CFU} / \mathrm{mL}$. The probiotic culture and the prebiotic components have no effect on the physicochemical characteristics and texture properties of the juices, but polydextrose and probiotic culture impact negatively on the sensory acceptance. The prebiotic components present no protective action on probiotics during storage.

\section{Funding}

This research received no external funding.

\section{Acknowledgments}

This research has no acknowledgment.

\section{Conflicts of Interest}

The authors declare no conflict of interest.

\section{References}

1. Hill, C.; Guarner, F.; Reid, G.; Gibson, G.R.; Merenstein, D.J.; Pot, B.; Morelli, L.; Canani, R.B.; Flint, H.J.; Salminen, S.; Calder, P.C.; Sanders, M.E. The International Scientific Association for Probiotics and Prebiotics consensus statement on the scope and appropriate use of the term probiotic. Nature Reviews Gastroenterology \& Hepatology 2014, 11, 506-514, https://doi.org/10.1038/nrgastro.2014.66.

2. Cuevas-González, P.F.; Liceaga, A.M.; Aguilar-Toalá, J.E. Postbiotics and paraprobiotics: From concepts to applications. Food Research International 2020, 136, https://doi.org/10.1016/j.foodres.2020.109502.

3. Sperry, M.F.; Silva, H.L.A.; Balthazar, C.F.; Esmerino, E.A.; Verruck, S.; Prudencio, E.S.; Neto, R.P.C.; Tavares, M.I.B.; Peixoto, J.C.; Nazzaro, F.; Rocha, R.S.; Moraes, J.; Gomes, A.S.G.; Raices, R.S.L.; Silva, M.C.; Granato, D.; Pimentel, T.C.; Freitas, M.Q.; Cruz, A.G. Probiotic Minas Frescal cheese added with L. casei 01: Physicochemical and bioactivity characterization and effects on hematological/biochemical parameters of hypertensive overweighted women - A randomized double-blind pilot trial. Journal of Functional Foods 2018, 45, 435-443, https://doi.org/10.1016/j.jff.2018.04.015.

4. Vasconcelos, F.M.; Silva, H.L.A.; Poso, S.M.V.; Barroso, M.V.; Lanzetti, M.; Rocha, R.S.; Graça, J.S.; Esmerino, E.A.; Freitas, M.Q.; Silva, M.C.; Raices, R.S.L.; Granato, D.; Pimentel, T.C.; Sant'Ana, A.S.; 
Cruz, A.G.; Valença, S.S. Probiotic Prato cheese attenuates cigarette smoke-induced injuries in mice. Food Research International 2019, 123, 697-703, https://doi.org/10.1016/j.foodres.2019.06.001.

5. Cordeiro, M.A.; Souza, E.L.S.; Arantes, R.M.E.; Balthazar, C.F.; Guimarães, J.T.; Scudino, H.; Silva, H.L.A.; Rocha, R.S.; Freitas, M.Q.; Esmerino, E.A.; et al. Fermented whey dairy beverage offers protection against Salmonella enterica ssp. enterica serovar Typhimurium infection in mice. Journal of Dairy Science 2019, 102, https://doi.org/10.3168/jds.2019-16340.

6. Cordeiro, M.A.; Souza, E.L.S.; Arantes, R.M.E.; Balthazar, C.F.; Guimarães, J.T.; Scudino, H.; Silva, H.L.A.; Rocha, R.S.; Freitas, M.Q.; Esmerino, E.A.; Silva, M.C.; Pimentel, T.C.; Granato, D.; Costa, R.G.B.; Cruz, A.G.; Martins, F.S. Postprandial glycemia in healthy subjects: Which probiotic dairy food is more adequate? Journal of Dairy Science 2020, 103, 6756-6765, https://doi.org/10.3168/jds.2019-17401.

7. Rosa, L.S.; Santos, M.L.; Abreu, J.P.; Balthazar, C.F.; Rocha, R.S.; Silva, H.L.A.; Esmerino, E.A.; Duarte, M.C.K.H.; Pimentel, T.C.; Freitas, M.Q.; Silva, M.C.; Cruz, A.G.; Teodoro, A.J. Antiproliferative and apoptotic effects of probiotic whey dairy beverages in human prostate cell lines. Food Research International 2020, 137, https://doi.org/10.1016/j.foodres.2020.109450.

8. Santos, M.A.; Costa, G.M.; Dias, S.S.; Klososki, S.J.; Barão, C.E.; Gomes, R.G.; Pimentel, T.C. Pasteurised sugarcane juice supplemented with Lactobacillus casei and prebiotics: Physicochemical stability, sensory acceptance and probiotic survival. International Food Research Journal 2019, 26, 1315-1325.

9. Aspri, M.; Papademas, P.; Tsaltas, D. Review on non-dairy probiotics and their use in non-dairy based products. Fermentation 2020, 6, 1-20, https://doi.org/10.3390/fermentation6010030.

10. Grom, L.C.; Coutinho, N.M.; Guimarães, J.T.; Balthazar, C.F.; Silva, R.; Rocha, R.S.; Freitas, M.Q.; Duarte, M.C.K.H.; Pimentel, T.C.; Esmerino, E.A.; Silva, M.C.; Cruz, A.G. Probiotic dairy foods and postprandial glycemia: A mini-review. Trends in Food Science \& Technology 2020, 101, 165-171, https://doi.org/10.1016/j.tifs.2020.05.012.

11. da Silva, J.M.; Klososki, S.J.; Silva, R.; Raices, R.S.L.; Silva, M.C.; Freitas, M.Q.; Barão, C.E.; Pimentel, T.C. Passion fruit-flavored ice cream processed with water-soluble extract of rice by-product: What is the impact of the addition of different prebiotic components? Lwt 2020, 128, https://doi.org/10.1016/j.lwt.2020.109472.

12. Valero-Cases, E.; Cerdá-Bernad, D.; Pastor, J.J.; Frutos, M.J. Non-dairy fermented beverages as potential carriers to ensure probiotics, prebiotics, and bioactive compounds arrival to the gut and their health benefits. Nutrients 2020, 12, https://doi.org/10.3390/nu12061666.

13. da Costa, G.M.; de Carvalho Silva, J.V.; Mingotti, J.D.; Barão, C.E.; Klososki, S.J.; Pimentel, T.C. Effect of ascorbic acid or oligofructose supplementation on L. paracasei viability, physicochemical characteristics and acceptance of probiotic orange juice. LWT - Food Science and Technology 2017, 75, 195-201, https://doi.org/10.1016/j.lwt.2016.08.051.

14. Barbalho, S.M.; Bueno Ottoboni, A.M.M.; Fiorini, A.M.R.; Guiguer, É.L.; Nicolau, C.C.T.; Goulart, R. de A.; Flato, U.A.P. Grape juice or wine: which is the best option? Critical Reviews in Food Science and Nutrition 2020, 1-14, https://doi.org/10.1080/10408398.2019.1710692.

15. Restani, P.; Fradera, U.; Ruf, J.C.; Stockley, C.; Teissedre, P.L.; Biella, S.; Colombo, F.; Lorenzo, C. Di Grapes and their derivatives in modulation of cognitive decline: a critical review of epidemiological and randomized-controlled trials in humans. Critical Reviews in Food Science and Nutrition 2020, 1-11, https://doi.org/10.1080/10408398.2020.1740644.

16. Pimentel, T.C.; Madrona, G.S.; Garcia, S.; Prudencio, S.H. Probiotic viability, physicochemical characteristics and acceptability during refrigerated storage of clarified apple juice supplemented with Lactobacillus paracasei ssp. paracasei and oligofructose in different package type. LWT - Food Science and Technology 2015, 63, 415-422, https://doi.org/10.1016/j.lwt.2015.03.009.

17. Miranda, R.F.; de Paula, M.M.; da Costa, G.M.; Barão, C.E.; da Silva, A.C.R.; Raices, R.S.L.; Gomes, R.G.; Pimentel, T.C. Orange juice added with L. casei: is there an impact of the probiotic addition methodology on the quality parameters? Lwt 2019, 106, 186-193, https://doi.org/10.1016/j.lwt.2019.02.047.

18. Porto, M.R.A.; Okina, V.S.; Pimentel, T.C.; Prudencio, S.H. Beet and orange mixed juices added with Lactobacillus acidophilus. Nutrition \& Food Science 2017, 48, https://doi.org/10.1108/NFS-06-2017-0108.

19. Okina, V.S.; Porto, M.R.A.; Pimentel, T.C.; Prudencio, S.H. White grape juice added with Lactobacillus paracasei ssp. probiotic culture. Nutrition and Food Science 2018, 48, https://doi.org/10.1108/NFS-08-20170176.

20. Miranda, R.F.; da Silva, J.P.; Machado, A.R.F.; da Silva, E.C.; de Souza, R.C.; Marcolino, V.A.; Klososki, S.J.; Pimentel, T.C.; Barão, C.E. Impact of the addition of Lactobacillus casei and oligofructose on the quality parameters of orange juice and hibiscus tea mixed beverage. Journal of Food Processing and Preservation 2019, 43, 1-11, https://doi.org/10.1111/jfpp.14249.

21. Gibson, G.R.; Hutkins, R.; Sanders, M.E.; Prescott, S.L.; Reimer, R.A.; Salminen, S.J.; Scott, K.; Stanton, C.; Swanson, K.S.; Cani, P.D.; Verbeke, K.; Reid, G. Expert consensus document: The International Scientific Association for Probiotics and Prebiotics (ISAPP) consensus statement on the definition and scope of prebiotics. Nature Reviews Gastroenterology \& Hepatology 2017, 14, 491-502, https://doi.org/10.1038/nrgastro.2017.75. 
22. Fonteles, T.V.; Rodrigues, S. Prebiotic in fruit juice: processing challenges, advances, and perspectives. Current Opinion in Food Science 2018, 22, 55-61, https://doi.org/10.1016/j.cofs.2018.02.001.

23. Guimarães, J.T.; Balthazar, C.F.; Silva, R.; Rocha, R.S.; Graça, J.S.; Esmerino, E.A.; Silva, M.C.; Sant'Ana, A.S.; Duarte, M.C.K.H.; Freitas, M.Q.; Cruz, A.G. Impact of probiotics and prebiotics on food texture. Current Opinion in Food Science 2020, 33, 38-44, https://doi.org/10.1016/j.cofs.2019.12.002.

24. Pimentel, T.C.; Prudencio, S.H.; Rodrigues, S. Néctar de pêssego potencialmente simbiótico. 2011; pp. 455464.

25. Forssten, S.D.; Röytiö, H.; Hibberd, A.A.; Ouwehand, A.C. The effect of polydextrose and probiotic lactobacilli in a Clostridium difficile- infected human colonic model. Microbial Ecology in Health \& Disease 2015, 26, https://doi.org/10.3402/mehd.v26.27988.

26. Closa-Monasterolo, R.; Ferré, N.; Castillejo-DeVillasante, G.; Luque, V.; Gispert-Llaurado, M.; ZaragozaJordana, M.; Theis, S.; Escribano, J. The use of inulin-type fructans improves stool consistency in constipated children. A randomised clinical trial: pilot study. International Journal of Food Sciences and Nutrition 2017, 68, 587-594, https://doi.org/10.1080/09637486.2016.1263605.

27. AOAC AOAC Official Methods of Analysis CREATE. 2016; pp. 9-10.

28. Shah, N.P.; Ding, W.K.; Fallourd, M.J.; Leyer, G. Improving the stability of probiotic bacteria in model fruit juices using vitamins and antioxidants. Journal of Food Science 2010, 75, 278-282, https://doi.org/10.1111/j.1750-3841.2010.01628.x.

29. Slinkard, K.; Singleton, V. Total phenol analysis: automation and comparison with manual methods. American Journal of Enology and Viticulture 1977, 28, 49-55.

30. Tharmaraj, N.; Shah, N.P. Selective enumeration of Lactobacillus delbrueckii ssp. bulgaricus, Streptococcus thermophilus, Lactobacillus acidophilus, bifidobacteria, Lactobacillus casei, Lactobacillus rhamnosus, and propionibacteria. Journal of Dairy Science 2003, 86, 2288-2296, https://doi.org/10.3168/jds.S00220302(03)73821-1.

31. Dutcocky, S.D. Análise Sensorial de Alimentos. Curitiba: Ed. Champagnat. 2007; pp. 239.

32. Bender, A.; Souza, A.L.K. de; Caliari, V.; Souza, E.L. de; Malgarim, M.B.; Camargo, S.S. Características físico-químicas de sucos integrais elaborados a partir de uvas da espécie Vitis rotundifolia. Brazilian Journal of Food Technology 2019, 22, 1-10, https://doi.org/10.1590/1981-6723.31018.

33. Rodrigues, R.F.C.; Lima, A.; Melo, A.C.F.L.; Trindade, R.A. Physicochemical characterisation, bioactive compounds and in vitro antioxidant activities of commercial integral grape juices. International Food Research Journal 2019, 26, 469-479.

34. Rizzon, L.A.; Miele, A. Analytical characteristics and discrimination of Brazilian commercial grape juice, nectar, and beverage. Food Science and Technology 2012, 32, 93-97, https://doi.org/10.1590/s010120612012005000015.

35. Dani, C.; Oliboni, L.S.; Vanderlinde, R.; Bonatto, D.; Salvador, M.; Henriques, J.A.P. Phenolic content and antioxidant activities of white and purple juices manufactured with organically- or conventionally-produced grapes. Food and Chemical Toxicology 2007, 45, 2574-2580, https://doi.org/10.1016/j.fct.2007.06.022.

36. Veena, N.; Nath, S.B.; Arora, S. Polydextrose as a functional ingredient and its food applications: A review. Indian Journal of Dairy Science 2016, 69, 239-251.

37. Batista, A.L.D.; Silva, R.; Cappato, L.P.; Ferreira, M.V.S.; Nascimento, K.O.; Schmiele, M.; Esmerino, E.A.; Balthazar, C.F.; Silva, H.L.A.; Moraes, J.; Pimentel, T.C.; Freitas, M.Q.; Raices, R.S.L.; Silva, M.C.; Cruz, A.G. Developing a synbiotic fermented milk using probiotic bacteria and organic green banana flour. Journal of Functional Foods 2017, 38, 242-250, https://doi.org/10.1016/j.jff.2017.09.037.

38. Campbell, K. What makes a synbiotic? ISAPP provides a sneak peek at the forthcoming international scientific consensus definition. Available at https://isappscience.org/what-makes-a-synbiotic-isappprovides-a-sneak-peek-at-the-forthcoming-international-scientific-consensus-definition/. Accessed in 26 june 2020. 2020. 